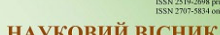

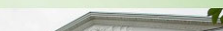

Tus

औiा

СЕРЯ “СЛЬСБКОГОСПОДАРСККГ НАУКК

Том 23 № 95 2021
Науковий вісник Яьвівського національного університету ветеринарної медицини та біотехнодогій імені С.3. Гжицького. Серія: Сільськогосподарські науки

\section{Scientific Messenger of Lviv National University of Veterinary Medicine and Biotechnologies. Series: Agricultural sciences}

UDC 639.311:615

\title{
Technologies of carp growing and their features
}

Yu. V. Loboiko, Ye. O. Barylo, Yu. R. Vachko, B. S. Barylo, I. R. Rachkivska

Stepan Gzhytskyi National University of Veterinary Medicine and Biotechnologies Lviv, Ukraine

Article info

Received 22.04.2021

Received in revised form 24.05.2021

Accepted 25.05.2021

Stepan Gzhytskyi National University of Veterinary Medicine and Biotechnologies Lviv, Pekarska Str., 50, Lviv. 79010, Ukraine. Tel.: +38-097-552-07-04 E-mail:llobojko@ukr.net
Loboiko, Yu. V., Barylo, Ye. O., Vachko, Yu. R., Barylo, B. S., \& Rachkivska, I. R. (2021). Technologies of carp growing and their features. Scientific Messenger of Lviv National University of Veterinary Medicine and Biotechnologies. Series: Agricultural sciences, 23(95), 54-59. doi: $10.32718 /$ nvlvet-a9507

Carp is one of the few fish farms for which a wide range of technologies has been developed: from extensive, with minimal human intervention in the formation of fish productivity of the reservoir, to intensive, with the most controlled production conditions. Carp has many biological features, enhanced by centuries of breeding work, making this fish extremely "technological", able to more or less fully realize the genetically determined bioproductive properties of different breeding technologies. Technologies for growing commercial carp according to the level of intensification of the production process can be divided into extensive (grazing), semi-intensive, intensive, and continuous, as a distinct type of intensive technology for growing carp in ponds and pools. Extensive technology assumes that the fish will feed exclusively on natural food, zooplankton, and bottom fauna. In this case, the cost of growing carp will be the lowest; the fish will be called "ecological", but the growth of individuals will be insignificant. Semi-intensive technology assumes that carp feed on natural feeds, and their energy needs are met by providing carbohydrate additives to feed. Intensive technology believes that carp feeding with compound feeds with high protein content is used, which allows achieving productivity of 3-20 tons/ha. This system requires the highest costs, although it gives the highest performance. The pond must provide additional aeration and water flow to prevent contamination of the reservoir and the development of fish diseases. The main disadvantage of popular carp growing technologies is their staging. All operations are carried out strictly one after another in specialized ponds. Moreover, each stage ends with the descent of the tanks, and the fish are transplanted several times from one to another (from spawning to juvenile, from them to nursery). During this, the carp is injured, which negatively affects its productivity and inevitably leads to waste. To remedy this, fish farming is now using continuous rearing technology. The choice of technology for growing carp is a responsible task on which the profitability of fisheries depends.

Key words: extensive (grazing) technology, intensive technology, semi-intensive technology, continuous technology, carp, fish farming, fish productivity, ponds, reservoir, polyculture, artificial feed.

\section{Технології вирощування коропа та їх особливості}

\author{
Ю. В. Лобойко, Є. О. Барило, Ю. Р. Вачко, Б. С. Барило, І. Р. Рачківська
}

Львівський національний університет ветеринарної медицини та біотехнологій імені С. 3. Гжицького, м. Львів, Україна

Короп - один із тих небагатьох об'єктів рибничтва, для одержання товарної продукиї якого розроблено широкий спектр технологій: від екстенсивних, з мінімальним втручанням людини у процес формування рибопродуктивності водойми, до інтенсивних, з максимально контрольованими умовами виробничтва продукиії. Короп має ряд біологічних особливостей, підсилених багатовіковою селекційною роботою, які роблять иңю рибу надзвичайно «технологічною», здатною більш-менш повно реалізувати генетично обумовлені біопродуктивні властивості за різних технологій вирощування. Технології вирощування товарного коропа за рівнем інтенсифікації виробничого процесу можна розділити на екстенсивну(випасну), напівінтенсивну, інтенсивну та безперервну, як окремий різновид інтенсивної технології виромування коропа в ставах $і$ басейнах. Екстенсивна технологія передбачає, шчо риба буде харчуватися виключно натуральними кормами, тобто зоопланктоном, фауною дна і т. д. У такому випадку витрати на 
вирощування коропа будуть найменшими, риба буде щчо називається «екологічною», але й приріст особин буде незначним. Напівінтенсивна технологія передбачає, щуо короп харчується натуральними кормами, а його потреба в енергї задовольняється завдяки підгодівлі вуглеводними добавками до кормів. Інтенсивна технологія передбачає, що застосовується годування коропів комбікормами з високим вмістом білків, щзо дозволяє досягти продуктивності в 3-20 тонн/га. Ця система вимагає найбільших витрат, хоча $і$ дає найвищу продуктивність. При иьому в ставі необхідно забезпечити додаткову аерачію $і$ проточність води, иоб не допускати забруднення водойми і розвитку хвороб риб. Головним недоліком популярних технологій вирощування коропа є їх етапність. Всі операції здійснюються одна за одною в спеціалізованих ставах. Причому кожна стадія завершується спуском резервуарів, і риба при ичьому кілька разів пересаджується з одного в інший (з нерестових у малькові, з них - у вирошувальні і т.д.). Під час иього короп травмується, а цее негативно впливає на його продуктивність і неминуче призводить до зниження виживаності. Щоб усунути це, зараз в рибництві застосовують безперервну технологію вирощування. Вибір тої чи іншої технологї вирощування коропа - відповідальне завдання, від якого залежить прибутковість рибогосподарської діяльності.

Ключові слова: екстенсивна (випасна) технологія, інтенсивна технологія, напівінтенсивна технологія, безперервна технологія, короп, вирощування риби, рибопродуктивність, стави, водосховища, полікультура, итучні корми.

\section{Introduction}

In technological practice, many technological schemes of fish farming at different stages have been developed. Given the specific natural and economic conditions, one or another scheme can be adopted with an economic assessment of each option at all stages of production. Each technology provides a comprehensive combination and cooperation of aquaculture production and integrated material and labor resources. Fish and fish products must meet specific requirements regarding their quantity, quality, and cost. Considerable attention should be paid to the optimization of production processes and production, the introduction of resource-saving techniques, fuller use of resource potential, accelerating the payback period of capital investments, the efficiency of fixed assets and working capital, mechanization and automation of production processes, rational use of biological resources (Rahman, 2015; Vachko et al., 2020; Vodianitskyi et al., 2020; Kofonov et al., 2020; Prychepa et al., 2021; Hrynevych et al., 2021).

One of the main advantages in breeding and growing carp is its simplicity: this heat-loving fish, however, tolerates winter well, hibernating, low oxygen levels, and poor water flow. Carp does not go through food: it gets its food at all levels of the water layers of the reservoir - from the bottom to the surface, feasting on insect larvae, slugs, tadpoles, algae, and plants, and others (Ianinovych et al., 2010; Al-Jader \& Al-Sulevany, 2012). This type of fish is also characterized by rapid growth, and an already oneyear-old individual can reach a mass of $1 \mathrm{~kg}$. Females are characterized by high fertility; depending on their age and the water temperature of the reservoir, they can sweep up to 1.5 million eggs (Vseticková et al., 2012). The purpose of this article is to explore general information about the various technologies of carp farming, their advantages, and difficulties that may arise when choosing a technology and in the process of its use.

\section{Results and Discussion}

\section{Extensive (Grazing) Technology}

In current conditions in many fisheries, there are some changes in technologies and methods of fish farming. Their main goal is to ensure resource conservation in fish farming, maximum use of the biological potential of water bodies, the more comprehensive introduction of fish polyculture with their grazing content, reduction of the use of feed and fertilizers, etc (Balami \& Pokhrel, 2020).
When growing carp fish on natural feed for grazing (without feeding artificial meals) next to the carp, an important place is given to the optimal set of objects of the multi-culture of fish with a different spectrum of nutrition, in particular, herbivorous fish - white and variegated silver carp, grass carp, and buffalo, pilengas, etc. These fish farms have a high potential for growth (Chirwa et al., 2017). There is no or weak competition between them for feeding on natural fodder bases. In these conditions, particular importance is attached to the choice of the optimal ratio of objects of fish multi-culture, taking into account their trophic levels and the directional formation of the natural forage base of ponds (Van Niekerk \& Moloi, 2018).

Starting with a water temperature of $7{ }^{\circ} \mathrm{C}$, mineralnitrogen and phosphorus fertilizers are added to the pond water to ensure organic and mineral substances. Throughout the growing season, regular (every 10-15 days) analysis of the content in the water of such vital for the work of the natural ecosystem ponds of nutrients as nitrogen and phosphorus (Shava \& Gunhidzirai, 2017). According to the biological need, mineral fertilizers are applied to the ponds, bringing the level of nitrate-nitrogen in the water to $2 \mathrm{mgN} / 1$ and phosphorus to $0.5 \mathrm{mgP} / 1$ (Shava \& Gunhidzirai, 2017). To prevent and improve the ecological condition of ponds during the growing season once a month, and if necessary - more often carry out their liming at a rate of not more than $150 \mathrm{~kg} / \mathrm{ha}$ per application (Kovalenko et al., 2014).

Subject to the implementation of these measures and regular fish farming and biological control in the ponds, the grazing form of carp farming achieves optimal indicators of development of the natural feed base, due to which fish are raised. The average seasonal biomass of natural fodder base in ponds should not be lower: for phytoplankton - 20-30 mg/l (but not higher than $80 \mathrm{mg} / \mathrm{l}$ ); zooplankton $-8-12 \mathrm{mg} / \mathrm{l}$; zoobenthos $-3-5 \mathrm{~g} / \mathrm{m}^{2}$ (Vachko et al., 2020).

Experience shows that the productive potential of ponds in the conditions of grazing technology of carp breeding in the optimal polyculture (both species and quantitative ratio) taking into account the trophic levels of fish and the implementation of these intensification measures allow obtaining fish productivity $1-1.5 \mathrm{t} / \mathrm{ha}$ (Ianinovych et al., 2010).

A positive feature of this technology is its resourcesaving nature, due to the maximum realization of its bioproductive potential of the reservoir and, accordingly, the minimum amount of financial costs associated with 
the technological process of carp farming (Bekh, 2009). In addition, marketable fish products obtained by this technology may fall into the category of organically pure products because fish do not use artificial feed for feeding carp. Stimulate the development of forage organisms in the reservoir mainly uses organic fertilizers of local origin, particularly fresh manure or humus of cattle (Hadjinikolova, 2008; Loboiko, 2020).

In current conditions, when there is an acute shortage of natural resources and, first of all, water resources on the planet, the question of their rational use becomes especially urgent. The use of reservoirs comprehensively (for fish breeding purposes, for irrigation, for growing carps) allows you to minimize the cost of land areas and the consumption of fresh water for obtaining various fish products (Vachko, 2020). In addition, it has become relevant to obtain environmentally friendly food products for which production technologies have not yet been sufficiently developed in modern conditions.

To obtain environmentally friendly products in integrated biotechnology, the following restrictions are introduced:

- restrictions on the stocking density of farmed objects, and for fish farming, a return to carp production in pasture aquaculture;

- using methods of natural reproduction, without the use of hormones and antibiotics;

- restriction in the use of feed additives, for carp this is the widespread use of the natural food base of reservoirs for growing;

- refusal to use inorganic fertilizers;

- prevention of diseases through prophylaxis instead of treatment with the help of synthetic drugs and antibiotics (for carp, this is the improvement of fish farms by means of flying ponds);

- rejection of the use of herbicides, synthetic pesticides, and in fish farming - the use of biological ameliorators in the fight against overgrowth of ponds and rice paddies;

- limiting energy consumption during water injection, over-tillage and water use (Hadjinikolova, 2007; Bekh, 2015; Ćirić, 2015).

Due to the rise in prices for concentrated fish feed and heat and energy sources, a decrease in the profitability of pond fish production is observed. The increase in the cost of growing marketable fish negatively affects its competitiveness, and difficulties arise in the sale of products. In the current economic conditions, resource-saving fish farming technologies are becoming especially relevant, which make it possible to significantly reduce the costs of expensive concentrated feed and, as a result, reduce the cost of growing a unit of fish products (Vachko, 2020).

The experience of the countries of the near and far abroad shows that the pasture technology of fish farming and especially its modifications, taking into account local soil and climatic conditions, allow, without the use of concentrated feed, to achieve fish productivity from a unit area sufficient for the recognition of production as highly profitable (Van Niekerk, 2018). So, in South America, Asia, Africa, due to the use of polyculture of fish from local aboriginal species and introduced species - herbivorous fish, without fertilizers, it is possible to achieve fish productivity up to $300 \mathrm{~kg} / \mathrm{ha}$ (Loboiko, 2020). Stimulating the development of the feed base of ponds by introducing mineral and organic fertilizers allows increasing fish production up to 2-3 t/ha (Bekh, 2009; Bekh \& Oleshko, 2015).

The disadvantage of this technology is the relatively low fish productivity and, accordingly, revenue per unit area of the reservoir, compared to other technologies, where to increase the yield of fish products used carp feeding artificial feed, more intensive use of fertilizers, and many other means to intensify production (Ćirić et al., 2015). Under grazing technology, the share of indirect costs in the cost of production of marketable products, such as rent for the use of water, costs for fish protection, water use, wages, administrative fees, will be much higher than for intensive technologies (Koba et al., 2013).

At the same time, grazing technology under many conditions may be the only possible form of fishery use of the reservoir. In particular:

- when growing carp in a non-draining reservoir, not adapted for intensive fishing (stiffness and complex relief of the reservoir bottom, significant development of thickets of higher aquatic vegetation), when it is impossible to catch a sufficient number of fish;

- when growing carp in a fishery reservoir of complex use, when, according to the requirements of the primary water user, feeding fish in it and taking measures to intensify the development of natural feed base is prohibited (for example, in a drinking water reservoir or a technical reservoir with high primary water quality requirements) (Ianinovych et al., 2010).

\section{Intensive technology}

Intensive technology of carp farming provides a significant increase in fish productivity and, accordingly, an increase in revenue per unit area of the reservoir due to the simultaneous application of a set of measures:

- the use of high density of carp planting, which far exceeds the capacity of the reservoir to provide aliens with natural food (Martseniuk, 2017; Mojer et al., 2021);

- intensive feeding of carp with artificial feed mixtures;

- formation of the optimal composition of fish polyculture, to make fuller use of different groups of natural forage organisms of the reservoir (Kolesnyk, 2011);

- fertilization of the reservoir to intensify the development of natural fodder base;

- maintaining the parameters of the quality of the aquatic environment for carp fish within the optimal values due to regular water exchange in the ponds, the introduction of quicklime into the ponds (Martseniuk, 2017);

- carrying out many treatment and prevention measures due to the high risk of carp diseases with its high density in the reservoir and the low level of provision of carp fish with natural food, the most complete in terms of quality composition (Szüics et al., 2007).

The yield of marketable fish products per unit area of the reservoir by intensive fish farming technology significantly exceeds the value of natural fish productivity of the reservoir. It will depend on the degree of intensification of the production process and ensuring the required quality of the aquatic environment (Li et al., 2013). Fish production of fully drained and well-supplied ponds by intensive 
technology (namely in such ponds and you can use this technology) from 1 ha during the growing season can be 2000-2500 kg of carp fish even more (Ianinovych et al., 2010). As the main object of fish farming by intensive technology, the share of carp in the total catch will be 60 $75 \%$ or more (Rahman, 2015).

The advantage of intensive technology is a significant reduction, compared to grazing and semi-intensive technologies, the share of costs in the cost of marketable products that do not directly affect the number of farmed fish but are required to ensure the production process (rent mentioned above, water use, administrative costs), due to their "dissolution" in a more significant amount of carp grown (Nikolova, 2013).

The "disadvantages" of this technology include:

- the need to attract significant financial resources to ensure the production process (for the purchase of feed, fertilizers, medicines, fish stocking (Hrynzhevskyi \& Pshenychnyi, 2007);

The increase in fish productivity of the pond is not equal to the rise in fish stocking density. In addition, when receiving each additional kilogram of fish products per unit area of the reservoir, the specific costs of artificial feed per unit of fish growth increase faster than fish productivity (Pshenychnyi et al., 2009);

- reduction of the average marketable weight of carp fish with increasing density of their landing due to the removal of living space and reducing the level of provision of utterly natural feed. It is known that in modern market conditions to obtain an economic result, the factor of fish quality is more important than its quantity (Martseniuk, 2017);

- commercial fish from intensively exploited fish ponds are unlikely to fall under the category of organic products because of their cultivation. They use intensive feeding with artificial feed, lime is added to ponds, mineral fertilizers containing some toxic elements that accumulate in fish, use many medicinal drugs for disease prevention (Gyalog et al., 2017).

Only unique reservoirs are suitable for the use of intensive carp production technology: fully draining ponds with a well-planned bed, with a reliable source of water supply, which will provide the technological need for a sufficient amount of good quality water (Kolesnyk, 2011). Adequate financial resources, good quality, and, at the same time, inextensive artificial feed, reliable fisheries, and a well-thought-out marketing policy are also prerequisites for achieving an acceptable result (Khan et al., 2016).

\section{Continuous Cultivation Technology}

Intensive technology of carp growing in modern conditions is combined with continuous technology. According to the so-called continuous technology, a simpler scheme for growing carp has been proposed in recent years. The technology is called continuous primarily because the cycle of carp rearing is not interrupted by transplanting it from pond to pond (Nikolova, 2013; Chirwa et al., 2017). At the same time, only juvenile and feeding (and in some cases only feeding) ponds are involved. It provides for the rearing of juvenile carp to a mass of 1-2 $\mathrm{g}$ and its further cultivation without transplants in one pond for two years (Ross et al., 2008).
The traditional technology for producing fish products in fish farms provides for many stages: obtaining offspring from fish, raising young animals, their wintering, and obtaining marketable (table) fish (Koba et al., 2013). Each step takes place in an age-appropriate reservoir. When transplanting from one pond to another, carp are caught, counted, sometimes processed in salt or other baths, transported over considerable distances in various containers (Martseniuk, 2017). During such operations, the fish is stressed and traumatized. As a result, after planting in a reservoir, carp grows poorly for a long time. In addition, early planting of carp in wintering ponds excludes their feeding in the autumn period when temperatures are sufficient for feeding.

The technology of continuous cultivation of carp products makes it possible to reduce the production stages. Also, an increase in the duration of the growing season for growing carp leads to a higher mass and contributes to better preparedness for prolonged winter starvation ( $\mathrm{Lu}$ et al., 2020). Continuous rearing means that juveniles are immediately planted in feeding ponds (Martseniuk, 2017). In them, young of the year feed until late autumn, hibernate, then marketable fish are grown here. Transplants from nursery and wintering ponds, which is typical for traditional technologies, are excluded in this case. Carp larvae are obtained by natural spawning or by factory methods, depending on weather conditions (Pshenychnyi et al., 2009; Al-Humairi et al., 2020).

\section{Semi-intensive Technology}

The semi-intensive technology of carp farming can be considered as a transitional form from grazing to intensive technology. This technology uses the positive aspects of the two previous ones: from grazing technology - the possibility of fuller use of the bioproductive potential of the reservoir (application of fish culture and fertilization of the reservoir), from intensive technology - the possibility of increasing fish yields by feeding artificial feed the main object of fish farming (Marković et al., 2016). In contrast, the intensive semi-intensive technology considers carp feeding with artificial feed as not the main but an additional means of intensifying production. Rather, it is not about intensive feeding. Still, rational, economically feasible feeding of carp with feed grain, grain processing waste, and inextensive artificial feed mixtures, usually locally produced, the fish productivity of carp can be 2-3 times higher than the biological productivity of a particular reservoir carp (Kovalenko et al., 2014). In this case, the productivity will be higher, approximately 700$1400 \mathrm{~kg} / \mathrm{ha}$. However, this diet does not fully meet the need of carp for protein. Thus, this technology and grazing can be attributed to the category of resource-saving technologies for the production of marketable fish products.

According to the semi-intensive technology of fish farming, it is possible to obtain 1000-1200 kg of fish per hectare per unit area of a fully drained reservoir, of which carp will account for about half of the products (Ianinovych et al., 2010). For a non-draining reservoir, this indicator will depend on many factors, particularly on the level of suitability of the reservoir for commercial fishing, the methods and tools used for fishing, and the intensity of their use. Semi-intensive carp farming tech- 
nology can be used in fish ponds and small reservoirs of complex use. It is allowed to use fish feed, fertilize the pond, and are more or less suitable for intensive fishing in quantities that ensure profitability (Kestemont, 1995; Hrynzhevskyi \& Pshenychnyi, 2007; Bekh, 2009).

\section{Conclusions}

Carp farming technologies range from grazing in natural and artificial reservoirs for fishery purposes to intensive cultivation with the feeding of fish with synthetic feed mixtures in ponds and pools with varying degrees of control over the quality of the aquatic environment. Technologies for growing commercial carp according to the level of intensification of the production process can be divided into grazing, semi-intensive, intensive, and industrial, as a distinct type of intensive technology for growing carp in swimming pools.

The extensive or grazing technology of carp farming is designed for the fullest possible use by cultivars of their feed resources of fish ponds without feeding fish with artificial feed mixtures. It is based on the targeted formation of the natural feed base of reservoirs and the appropriate set of cultivated fish in the context of the need to optimize and rational use of land and water resources, scientifically grounded resource-saving systems for conducting production on integrated reservoirs of complex purpose can give an economic effect. Semi-intensive carp farming technology is a combination of comprehensive and intensive technologies. This technology includes feeding carp with artificial feed as an additional means of intensifying production.

The intensive farming method includes feeding the fish and creating a rich forage base with the help of fertilization and reclamation of reservoirs. In modern fish farming, there are various technologies for intensive fish farming. Familiarization with them will allow you to choose the most appropriate one for your specific conditions. Continuous technology is helpful because the carp farming cycle is not interrupted by transplanting fish from one pond to another. Due to transportation, carp are traumatized and often die, so continuous technology is increasingly used in fish farming at the present stage. Thus, today there are many technologies for growing carp. Extensive (grazing), semi-intensive, intensive, and continuous, as a different intensive technology for growing carp, is the most effective. It is essential to weigh all the advantages and disadvantages and use the most appropriate technology depending on the natural environment and the ultimate goal.

\section{References}

Al-Humairi, K. O., Al-Tameemi, R. A., \& Al-Noor, S. S. (2020). Growth Performance and Feed Efficiency Assessment of Two Groups of Common Carp (Cyprinus carpio L.) Cultivated in Iraq. Basrah Journal of Agricultural Sciences, 33(1), 189-199. doi: $10.37077 / 25200860.2020 .33 .1 .14$.

Al-Jader, F. A. M., \& Al-Sulevany, R. S. (2012). Evaluation of common carp Cyprinus carpio L. performance fed at three commercial diets. Mesopotamia Journal of Agriculture, 40, 20-26. doi: 10.33899/magrj. 2012.60187.

Balami, S., \& Pokhrel, S. (2020). Production of Common Carp (Cyprinus carpio var. communis) and Grass Carp (Ctenopharyngodon idella) Fingerling in a Polyculture System in Chitwan, Nepal. J Aquac Fisheries, 4, 027. doi: 10.24966/AAF-5523/100027.

Bekh, V. V. (2009). Ekonomichna efektyvnist vyroshchuvannia maloluskatoho vnutrishnoporidnoho typu ukrainskoi ramchastoi porody koropa. Rybohospodarska nauka Ukrainy, 2, 110-113 (in Ukrainian).

Bekh, V. V., \& Oleshko, O. A. (2015). Optymizatsiia tekhnolohii vyroshchuvannia koropovykh vydiv ryb v polikulturi dlia nahulnykh stavovykh fermerskykh hospodarstv. Tekhnolohiia vyrobnytstva i pererobky produktsii tvarynnytstva, 2, 5-9 (in Ukrainian).

Chirwa, E. R., Kassam, D., Jere, W. L., \& Mtethiwa, A. (2017). A review of the farming of common carp (Cyprinus carpio L.) in Malawi: Policy research directions for aquaculture development in Malawi, 9(5), 42-51, doi: 10.5897/IJFA2017.0631.

Ćirić, M., Subakov-Simić, G., Dulić, Z., Bjelanović, K., Čičovački, S., \& Marković, Z. (2015). Effect of supplemental feed type on water quality, plankton and benthos availability and carp (Cyprinus carpio L.) growth in semi-intensive monoculture ponds. Aquaculture Research, 46(4), 777-788. doi: 10.1111/are.12230.

Gyalog, G., Oláh, J., Békefi, E., Lukácsik, M., \& Popp, J. (2017). Constraining Factors in Hungarian Carp Farming: An Econometric Perspective. Sustainability, 9(11), 2111. doi: 10.3390/su9112111.

Hadjinikolova, L., Nikolova, L., \& Stoeva, A. (2008). Comparative investigations on the nutritive value of carp fish meat (Cyprinidae), grown at organic aquaculture conditions. Bul. J. Agric. Sci., 14(2), 127-132.

Hrynevych, N., Prychepa, M., Kovalenko, Yu., Vodianitskyi, O., Svitelskyi, M., Fotin, O., Zahorui, L., Zharchynska, V., Gutyj, B., Kulish, S., Honcharenko, V., Velesyk, T., Sachuk, R., Stravsky, Ya., \& Boltyk, N. (2021). The role of macrophytes in waterfowl reproduction. Ukrainian Journal of Ecology, 11(2), 320-326. doi: 10.15421/2021_117.

Hrynzhevskyi, M. V., \& Pshenychnyi, D. R. (2007). Vyroshchuvannia dvolitok koropovo-sazanovykh hibrydiv $\mathrm{u}$ polikulturi. Rybohospodarska nauka Ukrainy, 1, 41-44 (in Ukrainian).

Ianinovych, Y. Ye., Hrytsyniak, I. I., Hrynzhevskyi, M. V., \& Shvets, T. M. (2010). Polikultura - shliakh do intensyfikatsii stavovoho rybnytstva. Rybohospodarska nauka Ukrainy, 4, 78-83 (in Ukrainian).

Kestemont, P. (1995). Different systems of carp production and their impacts on the environment. Aquaculture, 129(1-4), 347-372. doi: 10.1016/0044-8486(94)00292-v.

Khan, M. N., Shahzad, K., Chatta, A., Sohail, M., Piria, M., \& Treer, T. (2016). A review of introduction of common carp Cyprinus carpio in Pakistan: origin, purpose, impact and management. Croatian Journal of Fisheries, 74, 7180. doi: 10.1515/cjf-2016-0016.

Koba, S. A., Hryhorenko, T. V., \& Krazhan, S. A. (2013). Zhyvlennia ta rist tsoholitok koropa za spriamovanoho formuvannia pryrodnoi kormovoi bazy. Rybohospodarska nauka Ukrainy, 1, 38-44 (in Ukrainian). 
Kofonov, K., Potrokhov, O., Hrynevych, N., Zinkovskyi, O., Khomiak, O., Dunaievska, O., Rud, O., Kutsocon, L., Chemerys, V., Gutyj, B., Fijalovych, L., Vavrysevych, J., Todoriuk, V., Leskiv, K., Husar, P., \& Khumynets, P. (2020). Changes in the biochemical status of common carp juveniles (Cyprinus carpio L.) exposed to ammonium chloride and potassium phosphate. Ukrainian Journal of Ecology, 10(4), 137-147. doi: 10.15421/2020_181.

Kolesnyk, N. L. (2011). Rozpodil vazhkykh metaliv u lankakh hidroekosystemy staviv za intensyvnoi tekhnolohii vyroshchuvannia ryby. Rybohospodarska nauka Ukrainy, 3, 105-111 (in Ukrainian).

Kovalenko, V. O., Volichenko, Yu. M., \& Sherman, I. M. (2014). Shliakhy optymizatsii ta prohnozuvannia vyroshchuvannia tsoholitok koropovykh vydiv ryb v umovakh pivdnia Ukrainy. Rybohospodarska nauka Ukrainy, 2, 46-54 (in Ukrainian).

Li, X., Yan, Q., Xie, S., Hu, W., Yu, Y., Hu, Z. (2013). Gut Microbiota Contributes to the Growth of Fast-Growing Transgenic Common Carp (Cyprinus carpio L.). PLoS ONE, 8(5), e64577. doi: 10.1371/journal.pone.0064577.

Loboiko, Yu. V., Barylo, Ye. O., \& Barylo, B. S. (2020). Assessment of macrocyclic lacton group products for ectoparasitosis of carp. Scientific Messenger of LNU of Veterinary Medicine and Biotechnologies. Series: Veterinary Sciences, 22(98), 16-21. doi: 10.32718/nvlvet9803.

Lu, X., Chen, H. M., Qian, X. Q., \& Gui, J. F. (2020). Transcriptome analysis of grass carp (Ctenopharyngodon idella) between fast-and slow-growing fish. Comparative Biochemistry and Physiology Part D: Genomics and Proteomics, 35, 100688. doi: 10.1016/j.cbd.2020.100688.

Marković, Z., Stanković, M., Rašković, B., Dulić, Z., Živić, I., \& Poleksić, V. (2016). Comparative analysis of using cereal grains and compound feed in semi-intensive common carp pond production. Aquaculture international, 24(6), 1699-723. doi: 10.1007/s10499-016-0076-z.

Martseniuk, N. O. (2017). Stavovo-sadkova tekhnolohiia vyroshchuvannia ryby. Visnyk Sumskoho natsionalnoho ahrarnoho universytetu. Seriia: Tvarynnytstvo, 5(2), 70 74 (in Ukrainian).

Mojer, A. M., Taher, M. M., \& Al-Tameemi, R. A. (2021). Comparison of Growth for Cultivated Common carp, Cyprinus carpio Larvae between Earthen Ponds and Recirculation Aquaculture System. Basrah Journal of Agricultural Sciences, 34(1), 192-205. doi: $10.37077 / 25200860.2021 .34 .1 .17$.

Nikolova, L. (2013). Impact of Some Technological Factors on The Growth of Carp Fish Cyprinidae Reared in Autochthonous Polyculture. Bulgarian Journal of Agricultural Science, 19(6), 1391-1395. URL: http://agrojournal.org/19/06-33.

Prychepa, M., Hrynevych, N., Kovalenko, Yu., Vodianitskyi, O., Svitelskyi, M., Khomiak, O., Prysiazhniuk, N., Ishchuk, O., Sliusarenko, A., Kunovskii, J., Mihalskiy, O., Heiko, L., Trofymchuk, A., Gutyj, B., \& Levkivska, N. (2021). Diversity of aquatic animals in water bodies Opechen' (Dnipro floodplain, Ukraine). Ukrainian Journal of Ecology, 11(3), 285-291. doi: 10.15421/2021 173.
Prychepa, M., Hrynevych, N., Martseniuk, V., Potrokhov, O., Vodianitskyi, O., Khomiak, O., Rud, O., Kytsokon, L., Sliusarenko, A., Dunaievska, O., Gutyj, B., Pukalo, P., Honcharenko, V., Yevtukh, L., Bozhyk, L., Prus, V., \& Makhorin, H. (2021). Rudd (Scardinius Erythrophthalmus 1., 1758) as a bioindicator of anthropogenic pollution in freshwater bodies. Ukrainian Journal of Ecology, 11(2), 253-260. doi: 10.15421/2021_108.

Pshenychnyi, D. R., Hrytsyniak, I. I., Hrynzhevskyi, M. V., \& Shvets, T. M. (2009). Ekonomichna efektyvnist vyroshchuvannia dvolitok koropiv u stavakh u polikulturi z roslynoidnymy rybamy za intensyvnoiu tekhnolohiieiu. Rybohospodarska nauka Ukrainy, 4, 104-109 (in Ukrainian).

Rahman, M. M. (2015). Role of common carp (Cyprinus carpio) in aquaculture production systems. Frontiers in Life Science, 8(4), 399-410, doi: 10.1080/21553769.2015.1045629.

Ross, L. G., Martinez Palacios, C. A., \& Morales, E. J. (2008). Developing native fish species for aquaculture: the interacting demands of biodiversity, sustainable aquaculture and livelihoods. Aquaculture Research, 39(7), 675-683. doi: 10.1111/j.1365-2109.2008.01920.x.

Shava, E., \& Gunhidzirai, C. (2017). Fish farming as an innovative strategy for promoting food security in drought risk regions of Zimbabwe. Jamba, 9(1), 491. doi: 10.4102/jamba.v9i1.491.

Szücs, I., Stundi, L., \& Váradi, L. (2007). Carp farming in Central and Eastern Europe and a case study in multifunctional aquaculture. In: Leung, P.S., Lee, C.S., O'Bryan, P.J. (Eds.), Species and System Selection for Sustainable Aquaculture. Blackwell Publishing, Ames, 389-413. doi: 10.1002/9780470277867.ch26.

Vachko, Yu. R., Barylo, Ye. O., \& Chmyr, K. I. (2020). The results of cultivation and changes in fish and biological indicators of this year carp when using feed additives NuPro ${ }^{\circledR}$ та Bio-Mos. Scientific Messenger LNUVMB. Series: Agricultural sciences, 22(93), 40-44, doi: 10.32718/nvlvet-a9307.

Van Niekerk, J. A., \& Moloi, Z. (2018). Introduction of extensive cage culture systems for breeding of catfish (Clarius gariepinus) and common carp (Cyprin carpionus) at the aquaculture technology demonstration centre, Xhariep District: an agricultural extension perspective. South African Journal of Agricultural Extension, 46(1), 106-112. doi: 10.17159/2413-3221/2018/v46n1a466.

Vodianitskyi, O., Potrokhov, O., Hrynevych, N., Khomiak, O., Khudiyash, Y., Prysiazhniuk, N., Rud, O., Sliusarenko, A., Zagoruy, L., Gutyj, B., Dushka, V., Maxym, V., Dadak, O., \& Liublin, V. (2020). Effect of reserviour temperature and oxygen conditions on the activity of Na-K pump in embrios and larvae of perch, roach, and ruffe. Ukrainian Journal of Ecology, 10(2), 184-189. doi: $10.15421 / 202083$.

Vseticková, L., Adamek, Z., Rozkosný, M., \& Sedlacek, P. (2012). Effects of semi-intensive carp pond farming on discharged water quality. Acta ichthyologica et piscatoria, 42(3), 223-231. doi: 10.3750/aip2011.42.3.06. 